\title{
Student Worksheet Based on Scientific Approach to Improve Learning Outcomes and Creative Thinking Ability of Elementary Student
}

\author{
Akhmad Nurkholis \\ Madrasah Ibtidaiyah Negeri (MIN) 1 Magelang, Central Java, Indonesia \\ akhmadnurkholis21@gmail.com
}

\begin{abstract}
The scientific approach is an approach that is much highlighted in the implementation of the 2013 curriculum with learner-centered learning. Learning steps with this approach is designed so that learners are actively building concepts, principles or laws through the stages which includes observing, asking, reasoning, trying, and forming networks. The aims of this study are to develop student worksheets with a scientific approach to ecosystem balance learning material, describe the effect of student worksheets based on a scientific approach toward creative thinking skills, and explain the effect of student worksheets with a scientific approach to student learning outcomes. The method used in this study was preexperimental design with the research design of one-group pretest-posttest design. Subjects in this study were learners VB class Madrasah Ibtidaiyah Negeri/MIN (Islamic Elementary School) 1 Magelang which numbered 26 people. The data collection techniques used are interviews, observation and written tests. The results of the study show that the student worksheet based on the scientific approach can improve student learning outcomes of 4.50 from an average of 70.00 to 74.50 , and increasing the number of students completeness by 8 from 14 to 22 students who completed, the percentage of completed students increased by $30.76 \%$, from $53.85 \%$ to $84.61 \%$, the class completeness percentage of $84.61 \%$ exceeded the class completeness criteria was set at $80 \%$, and a positive effect on creative thinking skills of learners.
\end{abstract}

Keywords: Learning, scientific approach, student worksheets, creative thinking, learning outcomes 


\section{INTRODUCTION}

In the learning process we often encounter in schools or madrasah around us there are still many teachers who use teaching materials in the form of Student Worksheets (LKPD) made by other people as well as factory-made. Even though they are aware that the teaching materials they use are often not in accordance with the learning approach, learning content/material, contextual socio-cultural conditions in the students' environment, and do not support students to develop the ability to think critically and creatively. This condition is a matter of concern to us.

Machin (2014) in his research developed a lesson plan (RPP) on growth material that applied a scientific approach. The application of this approach has a positive effect on cognitive, affective and psychomotor learning outcomes and has achieved the specified classical completeness, i.e. more than $85 \%$ of all students who take part in learning. A Scientific approach enhance creative thinking skills, stated that mathematics learning was declared effective in increasing the ability to think creatively by indicators: creative thinking ability; improving creative thinking skill; using discovery learning model; and also increasing the curiosity and the skills to communicate the positive effect on the ability to think creatively (Davies et al., 2013:85; Rudyanto, 2014:4).

There are similarities in the approach used, namely the scientific approach, the difference is in the learning device and the learning model. Research by Machin was conducted to have an influence to improve learning outcomes, while research by Rudyanto. had a positive influence 
on improving the ability to think creatively. Thus researchers have hope by implementing Student Worksheets (LKPD) with a scientific approach can improve learning outcomes and have a positive effect on improving students' creative thinking skills.

Learning with a scientific approach is learning that applies the inquiry and scientific approach, where students can participate actively and play a direct role both in groups and individually to find concepts and principles during the learning process takes place. The task of the teacher in learning with this scientific approach is to provide direction to the learning process of students, provide correction and reinforcement of the concepts and principles found by students (Antlova et al., 2015:211; Marjan, et al., 2014). The scientific approach is also part of an active learning approach that is oriented or student centered approach, which in this approach the teacher acts as a facilitator, catalyst, motivator, and concept controller. In this approach learners are positioned as the main focus of attention, but teacher assistance is still needed, but the assistance decreases with increasing maturity of students or the higher level of the class (Daryanto, 2014: 26; Wisudawati \& Sulistiyowati, 2017: 18).

The learning approach is a philosophical foundation that becomes the frame and background of the ongoing learning activities. Learning is the process of interaction between students, between students and educators, and between participants and other learning resources in an educational environment that takes place so that students can develop 
attitudes, their knowledge and skills to achieve their intended goals (Sufairoh, 2016: 117).

The scientific approach has a close relationship with the scientific method. The scientific method in general is an activity that includes observations made to form hypotheses or collect data based on exposure to data obtained through experiments (Sani, 2017; 26-27) .

Scientific approach is an approach in the learning process that is designed so that students actively construct concepts, laws or principles through the stages of observing (to identify or find problems), formulate problems, submit or formulate hypotheses to collect data with various techniques, analyze data, interesting conclusions and communicating concepts, laws or principles found (Budiyanto \& Waluyo, 2016: 45; Saubas, 2015: 21).

Learning in the 2013 curriculum is scientifically based with five learning steps which include the components of observing, question, argue, trying, and forming networks (Sukiminiandari et al., 2015: 21). The scientific approach ordered students in influencing existing problems in the form of problems and hypotheses, caring for the environment, curiosity and love to read directly.

Student Worksheets (LKPD) are printed media in the form of books which generally contain a summary of material, practice questions, crossword puzzles, simple experiments, sheets of observation and discussion activities. LKPD includes print media as a result of developing print technology in the form of books and containing visual material 
(Arsyad, 2007: 21-22). LKPD above, it can be concluded that the LKPD is a print media in the form of worksheets in which there is a summary of the material, practice questions such as independent tasks, task groups, self-assessment and attitude assessment systematically arranged based on basic competencies specified (Hamdani, 2011:16).

Student Worksheets with a scientific approach are printed media in the form of worksheets which contain summaries of material; practice questions such as independent assignments, group assignments; and assessments are arranged based on scientific learning steps which include observing, asking, reasoning, trying, and forming networks.

Student Worksheets with a scientific approach has several advantages, including: increasing the activity of learners, encourage learners are able to learn by themselves or work independently, guiding learners towards planting and developing concepts through scientific principles, be more efficient to use than other media, it can be used anytime and anywhere, can be used for the application of guided discovery methods.

Creative thinking is one of the abilities developed in national education goals. The ability to think creatively is also a continuation of basic skills and is classified as high order competencies. Creative thinking ability is one of the desired capabilities in working, so it becomes important to be improved. According to Salam that think critically is synonymous with think creatively, that is a process through intuitive sense for creating something ability, estimating and making new conclusion, original smart and awesome (Walid, 2010: 94). While according to Ennis 
in, thinking critically is a thinking activity in a rational reflective manner focused on determination what should believe or do (Sapriya, 2014: 29). Based on the definitions, the form of behavior ability of creative thinking described as ability to generate many ideas/answers; ability to have broad ideas; able to produce ideas, answers or questions from different perspectives; ability provides a different direction of thinking (Fakhriyah et al., 2017: 82; Hardianti et al., 2017: 124; Soemartono, 2014: 270).

Thus based on some notions of critical thinking above, we can understand that critical thinking is a person's ability to communicate inwardly with himself in comparing and weighing things along with reasons carefully, detail analysis, and making decisions then new ideas in solving problems. Learning material of ecosystem balance tightly relate with daily and life environment of student. The material of ecosystem balance includes food chain and food webs, changes in food webs, the influence of human activities on the balance of ecosystems and efforts to maintain ecosystems.

The research objectives include: (1) to develop student worksheets with a scientific approach toward ecosystem balance learning material, (2) describe the effect of student worksheets based on scientific approaches toward creative thinking skills, and (3) explain the effect of student worksheets with scientific approach toward student learning outcomes.

The indicators of success set include: (1) Criteria for Class Completion (KKM) for learning outcomes is 70.0; (2) classical completeness is set at $80 \%$ of all students who attend learning. Starting 
from the problems mentioned above, it is necessary to solve a problem that is developing a Student Worksheet (LKPD) based on a scientific approach that encourages learning activities and leads to the ability to think creatively and improve student learning outcomes.

\section{METHODS}

This research is quantitative with descriptive data analysis. The data analyzed were data on learning outcomes before and after the experiment, analysis of data from observational results after experiment. The research design uses preliminary experimental research design method used to obtain initial information on research problems. The data collection techniques uses through observation and written tests. Observation is used to collect data about creative thinking skills, as well as written tests to collect data on learning outcomes of students. Population as the research subject used in this study are learners VB class of Madrasah Ibtidaiyah Negeri (MIN) 1 Magelang which is located at Kampung Santan Village Sumberrejo Mertoyudan, District of Magelang in the academic year 2018/2019. They are taking charge of thematic subject matter of Ecosystem balance in Natural Sciences which was held on 12 to 17 November 2018. The sample determination in this study uses a sampling technique based on certain considerations. With this technique, students are determined to $\mathrm{VB}$ totaling 26 people as a research sample with the consideration that the Student Worksheet with a scientific approach is expected to improve students' creative thinking skills and have a positive 
Mudarrisa: Jurnal Kajian Pendidikan Islam, Vol. 11, No. 1, 2019

effect on student learning outcomes that exceed the specified class completeness criteria.

\section{DISCUSSION}

Before discussing the improvement of learning outcomes using the LKPD with a scientific approach to the content of Natural Sciences lesson on ecosystem balance material, the researchers first stated that the minimum completeness criteria for the subjects were 70.00 and the clarity criteria were $80 \%$. Learning outcomes before and after the experiment is presented in Table 1.

Table1. Data of Minimum Completeness Criteria after experiment by LKPD

\begin{tabular}{ccc}
\hline No absence & Value Before Experiment & Value After Experiment \\
\hline 1 & 64 & 65 \\
\hline 2 & 64 & 73 \\
\hline 3 & 70 & 71 \\
\hline 4 & 65 & 71 \\
\hline 5 & 76 & 78 \\
\hline 6 & 73 & 71 \\
\hline 7 & 81 & 82 \\
\hline 8 & 63 & 79 \\
\hline 9 & 81 & 81 \\
\hline 10 & 60 & 65 \\
\hline 11 & 60 & 72 \\
\hline 12 & 76 & 82 \\
\hline 13 & 64 & 65 \\
\hline 14 & 70 & 81 \\
\hline 15 & 77 & 81 \\
\hline 16 & 60 & 71 \\
\hline 17 & 81 & 72 \\
\hline 18 & 60 & 71 \\
\hline 19 & 64 & 76 \\
\hline 20 & 72 & 80 \\
\hline 21 & 84 & 71 \\
\hline
\end{tabular}


Mudarrisa: Jurnal Kajian Pendidikan Islam, Vol. 11, No. 1, 2019

\begin{tabular}{ccc}
\hline No absence & Value Before Experiment & Value After Experiment \\
\hline 22 & 64 & 65 \\
\hline 23 & 78 & 81 \\
\hline 24 & 70 & 74 \\
\hline 25 & 60 & 77 \\
\hline 26 & 83 & 82 \\
\hline Average & 70.00 & 74.50 \\
\hline
\end{tabular}

Based on the table of learning outcomes above, it can be presented that the results of the implementation of Student Worksheets with a scientific approach to thematic subjects with Ecosystem Balance in Natural Sciences material based on the number of students completeness is as shown in the Table 2.

Table 2. Learning Outcomes Data by using LKPD

\begin{tabular}{|c|c|c|c|}
\hline $\begin{array}{l}\text { Learning } \\
\text { outcomes }\end{array}$ & $\begin{array}{c}\text { Complete before the } \\
\text { experiment }\end{array}$ & $\begin{array}{l}\text { Complete after the } \\
\text { experiment }\end{array}$ & Difference \\
\hline Written test & 14 & 22 & 8 \\
\hline
\end{tabular}

Implementation results of Student Worksheets on thematic subject matter in Natural Sciences lesson with a scientific approach on learning results based on the percentage in Table 3 .

Table 3. Learning Outcomes Data by a Scientifit Approach

\begin{tabular}{rccc}
\hline $\begin{array}{c}\text { Learning } \\
\text { outcomes }\end{array}$ & $\begin{array}{c}\text { Complete before the } \\
\text { experiment }\end{array}$ & $\begin{array}{c}\text { Complete after the } \\
\text { experiment }\end{array}$ & Difference \\
\hline Written test & 53.85 & $84,61 \%$ & $30.76 \%$ \\
\hline
\end{tabular}

Based on the three tables above, we can understand that from 26 students who were the subjects of the study attended the study and took the final test. The final test results show that the average test is 74.50 , a number of 
22 students meet or exceed the minimum completeness criteria (KKM), and 4 students have not met the KKM. According to percentage 84, $61 \%$ of students' completion and $14.5 \%$ have not yet finished. Therefore, based on KKM was set at 70.00 and criteria to completion grade is $80 \%$, then from this study can be obtained information that the implementation of learning of using a scientific approach based LKPD positive effect on the learning outcomes of learners and have reached the classical completeness based on the criteria determined, that is, more than $80 \%$ of all students who take part in the study have completely surpassed the minimum completeness criteria (KKM) set. While the growth in learning outcomes based on the average acquisition value, increase by 4.50 from an average of 70.00 to 74,50 . Based on the number of students completeness increase by 8 , from 14 to 22 students who completed. Based on the percentage of completeness of students, it increases by $30.76 \%$, from $53.85 \%$ to $84.61 \%$.

Analysis of the results of observations of the Creative Thinking Ability (KBK) obtained information that learners are categorized into three criteria namely the upper, middle, and bottom. The grouping of students in this study is based on the previous daily test results, as stated in (Wibowo, 2015) that grouping students in the category of high or upper group ability, moderate or middle group ability, and low ability or lower group based on the value of report cards or previous test scores. The upper group students in a class are grouped with upper class students in another class, as well as middle and lower group students. Grouping students based on cognitive abilities is useful for improving achievement, facilitating 
teachers in the learning process in the classroom, facilitating control and giving instructions, and facilitating the provision of reinforcement, facilitating teachers in using methods and adjusting learning materials to suit the needs of students, optimizing the use of space and time, increasing the participation of students in groups, optimizing the work of students according to their abilities. The grouping of students based on ability also has several disadvantages, including lowering expectations of student learning outcomes, lower group learners cannot be a learning model, the existence of negative assumptions for lower group students, difficulties in regulating class hours, behavior problems often arise in the lower group, decreased ability to convey ideas to lower group students in the upper class, and parents' anxiety if the teacher misplaced the child in a group.

The results of the analysis of the observations of the upper group students have no difficulty in generating many ideas and can apply various methods or methods that are different and precise in solving problems, but for the KBK indicators on aspects of authenticity need guidance. For the middle group there is no difficulty in generating many ideas and can apply various methods or methods that are different and precise in solving problems, but for the KBK indicator on aspects of authenticity and detail, it needs to get more attention. Analysis of the lower group obtained information that there was a positive influence on aspects of detail and proficiency, but the overall analysis was that this lower group needed to get more guidance and attention because based on observations of this group most of them were still experiencing difficulties. 
Mudarrisa: Jurnal Kajian Pendidikan Islam, Vol. 11, No. 1, 2019

\section{CONCLUSION}

This study develops student worksheets with a scientific approach to the content of Natural Sciences material on ecosystems balance. The implementation of the scientific approach in this study has a positive influence on students' creative thinking abilities which are characterized by being able to come up with many ideas and can use various methods that are different and appropriate in solving problems, and can improve student learning outcomes in terms of score, achievement of minimum individual completeness criteria, as well as an improvement in classical completeness.

\section{REFERENCES}

Arsyad, A. (2007). Learning Media. Jakarta: Raja Grafindo.

Budiyanto, M.A.K., \& Waluyo, L.A.M. (2016). Implementation of Scientific Approach in Learning in Basic Education in Malang. Proceeding Biology Education Conference, 13 (1), 46-51.

Daryanto. (2014). Approach to Scientific Learning Curriculum 2013 (Print I). Yogyakarta: Gava media.

Davies, D., Jindal-snape, D., Collier, C., Digby, R., Hay, P., \& Howe, A. (2013). Creative learning environments in education-A systematic literature review: Thinking Skills and Creativity, 8, 8091.

Fakhriyah, F., Masfuah, S., Roysa, M., Rusilowati, A., \& Rahayu, E. S. (2017). Student's Science Literacy in The. Jurnal Pendidikan IPA 
Indonesia, 6(1), 81-87.

Hamdani. (2011). Teaching and Learning Strategies. Bandung: Loyal Library. Hardianti, R. D., Taufiq, M., \& Pamelasari, S. D. (2017). The Development of Alternative Assessment Instrument in Webbased Scientific Communication Skill in Science Education Seminar Course: Jurnal Pendidikan IPA Indonesia, 6(1), 123-129.

Machin, A. (2014). Implementation of Scientific Approach, Character Planting and Conservation in Learning Growth Materials: Indonesian Science Education Journal, 3 (1), 28-35.

Marjan, J., \& et al. (2014). The Effect of Scientific Approach Learning on Biological Learning Outcomes and Science Process Skills of MA Students. You are allimat NW Pancor Selong, East Lombok Regency, West Nusa Tenggara: Journal of Science Education, 4 (1). Rudyanto, HE (2014). Discovery Learning Model with a Scientific Approach with Character Contents to Improve Creative Thinking Ability: Premier Educandum, 4 (1), 41-48.

Sani, RA (2017). Scientific Learning for Implementation of 2013 Curriculum. (YS Hayati, Ed.4th. Jakarta: Bumi Aksara.

Soemartono, T. (2014). Reconstruction of Education Policy in Jembrana Bali, Best Practices of Creative and Innovative Leadership Using Soft Systems Methodology based Action Research: In Procedia Social and Behavioral Sciences ,115.

Sapriya. (2014). Social Studies Education. Bandung: Teenager Rosdakarya. 
Mudarrisa: Jurnal Kajian Pendidikan Islam, Vol. 11, No. 1, 2019

Saubas, U. (2015). Implementation of the 2013 Curriculum through the Application of a Scientific Approach in Text-Based Indonesian Language Learning in Junior High Schools (SMP): EDUCATION - Journal of Education, 13 (1), 208-215.

Sufairoh. (2016). Scientific Approach \& K-13 Learning Model: Professional Education Journal, 5 (3), 116-125.

Sukiminiandari, YP, \& et al. (2015). Development of Physics Learning Modules: Proceedings of the National Seminar on Physics, IV, 161164.

Sumarmo, U. et al. (2012). Ability and Disposition of Logical, Critical and Creative Mathematical Thinking (Experiments on High School Students Using Problem-Based Learning and Think-Talk-Write Strategies): Mathematics and Natural Sciences Teaching Journal, 17 (1), 17. 269-282). Elsevier B.V

Walid, M. (2010). Humans and Critical thinking: Falasifa Journal, 1 (2), 93-103.

Wibowo, DH (2015). Application of Student Grouping Based on Achievement at the Primary School Level: Undip Psychology Journal, 14 (2), 148-159.

Wisudawati, AW, \& Sulistiyowati, E. (2017). Science Learning Methodology 3rd. Jakarta: Bumi Aksara. 